\title{
Malay Oral Literature on Billah Riverside and Flood Prevention
}

\author{
Wan Syaifuddin (Syaifuddin) \\ Post-Graduate Studies (Doctoral), Faculty of Cultural Studies \\ University of Sumatera Utara, Medan, Indonesia \\ profwsy@gmail.com
}

\begin{abstract}
This research reveals values in Malay oral Literature among people residing on Billah riverside, North Sumatera, Indonesia. This area is dangerous due tothe potential of flood, whereas its existence is also the cause of the flood. One of the causes is people's lack of awareness in maintaining mutual positive relationship between human and their environment proportionally. The research problem is to find out how oral literature's values guide society's behavior to preserve and not to damage their environment. The purpose of this research is to make sure those values tied up in people'smind and behavior living in on the riverside. The research useddescriptive qualitative with social and literature reception approach. This research showed that the values of Malay oral literature among society who live on Billah riverside in North Sumatera have relationship with their behavior, as those values have connection with people beliefs towards Islam. Those values can be applied as a flood prevention
\end{abstract}

Keywords: Oral literature, Billah river, Flood prevention

\section{INTRODUCTION}

Billah river is one of rivers in North Sumatera province, Indonesia. Based on the record of National Bureau of Flood Prevention (PNPB), Sumatera Office of River Territories (BWS) and Organization Office of River Bank Area (BPDAS) in North Sumatera, Indonesia, flood occursseveral times every year. Annual flood occurancedoes not necessarily meanwithout any reasons. In fact, one of the cause is the uncovered condition of forest at an upper area of Billah river caused by the people act near Billah river who cut down trees improperly (known as Hydrology Ecology) and at the lower areawas found improper structure and arrangement in houses and buildings, sanitary and drainage ( known as Hydrology Technical) [3]. It is clear that people, live at the riverside area, still have lack of awareness in understanding their mutual relationship with their environment.

The space orientation of Malay society basically refers to river territorial. In Malay society's belief, which is Islam, the esthetic dimension or the beauty of the river hasoutstanding values. Therefore, Malay society, in most social studies, is often called aquatic-religious society. Observing that behavior and the existence of the river, it clearly tells the river cosmic for Malay society on Billah riverside as the substance or creative concept for oral literature reflected in local wisdoms. Also,its existence can be used as guidance for society behavior in order to not to damage their environment and keep its beauty, so they can prevent flood.

Reseach on Malay oral literature's values as local wisdom on Billah riverside makes those values keep on existing in forming cultured, educated, noblecharacterized, and religious people because those values basically reflect and supply the society with sufficient needs. In other words, those values and norms in the texts are collective dreams due to its relevancy to various life aspects, including preserving the environment [6]. This includes a positive behavior to maintain the riverside area. But proper education to maintain the Billah river, referred to oral literature, systematically, directly, and creativelyhas not been done yet [8].

Based on this condition, the need of values as the part of local wisdom to maintain Billah river is highly needed. Therefore, on this $5^{\text {th }}$ International Conference on Applied Sciences, Art and Social for Community Development in the Asean 2018, the researcher presented a discussion of research on keeping and maintaining Billah river in North Sumatera, Indonesia. The purpose of this discussion is to anticipate every behavioral and cultural changes with local wisdom implementation, that is the values in Malay oral literature. Billahriver is one of the symbols of Labuhan Batu regency. In the Kesultanan Billah period, the political and economical activities of the city were centered around riverside. Based on the history record, Billah river was functioned as part of watertransportation using ships. This is still functional up to now although it was not as busy as before. [2].

\section{METHOD}

Values of Malay oral literature work could not be comprehended from the outer layer only, but it should be deeply dug through to the essence of the language, the rhythm of the voice and cultural utterances. It is the flesh tradition of Malay society. Therefore, to comprehend positive norms and values to increase the society behavior through mimesis of those values and norms, the work need to be reflected into daily life. For that, this research uses descriptive qualitative method which accordance with approach theory putting the role of the reader or the researcher in interpreting a work, that is Esthetic reception theory. 
The application of this approach is due to various factor, condition and situation. The researcher has different experiences and knowledge so the researcher will find different responds or opinions toward the texts [9]. The researcher, in his interaction process with Malay oral literature texts in Billah river, was unstable variable because of the condition and situation. The researcher responses can be done in various norms and values. He realized that if one text could be interpreted differently, it can be said that the text hasagood impact and this could be the criteria of its "esthetic values".

The analysis was begun by collecting the Malay oral literature works which live and develop in society. Then the researcherwas revealing and interpreting norms and values related to the Billahriver maintenance.

\section{RESULTS}

By recording the inventory, text content of Malay oral tradition, related to society's behavior to maintain the Billah riverside, a narration text and twelve cultural expressions or Petuah Adat were elaborated.

\section{Narration Text}

Informan Dato' Filiansyah and Pengadilan Pane: Title /Synopsis"Pelanduk Terkial-Kial"

Seorang pemuda bergelar Dato' Sungai meluahkan rintihan hatinya karena merasakan keadaan di sekitar sungai yang merana kelak dikemudian hari mencana juga terhadap makhluk-maklhuk yang hidup di banjaran sungai Billah. Konon rasanya kehidupan yang ada menguak rasa hingga kepada wanita-wanita menjauh terhadap lelaki atau perjaka-perjaka yang hidup di lingkungan banjaran Sungai Billah karena tidak bernasif baik. Suatu saat mengatasi keadaan ini Dato' Sungai membuka lahan pertanian di hamparan pinggir sungai Billah. Hamparan ini ia tanami dengan sayur mayur. Kelak ia bercita-cita bila sudah menghasilkan, maka ia akan membuktikan bahwa tidak sesungguhnya para lelaki tidak berdaya mengolah lingkungan sebagaimana perilaku wanita terhadapnya. Namun, saat hamparan sayur mayur dapat dituai, sayur mayur diranap terlebih dahulu oleh "entah siapa". Tiada kalah akal atas kebenciannya terhadap perbuatan itu, maka ia buat ranjau yang disebut "jerat sembilan". Jerat dapat menangkap pelakunya, yaitu "pelanduk betina” perambas sayur mayur yang ditanam. Oleh karena kaki pelandu betina terjerat ranjau, maka ia terkial-kial. Namun, saat pelanduk terkial-kial, sembari ia memanggil anaknya. Lalu anak pelanduk datang dan pelanduk mempersilakan anaknya untuk menyusu padanya. Dato' Sungai tidak jadi melaksanakan hajat marahnya, yaitu akan membunuh pelanduk betina. Melainkan Dato' berkata bukankah sungai sesungguhnya demi kehidupan makhluk ciptaanNya ,yang hidup di alam ciptaanNya?. Bukankah pelanduk memakan sayur mayur demi kehidupan anak-anaknya ?. Sejatinya pelanduk mebuka mata hati untuk ingat jasa ibunnya. Dato'Sungai sangat menghormati jasa-jasa seorang ibu?. Demikianlah ceritanya.
Table 1: Expressions /Petuah Adat

\begin{tabular}{|c|c|c|c|}
\hline No. & $\begin{array}{l}\text { Expressions/ } \\
\text { Petuah Adat }\end{array}$ & Informan & Description \\
\hline 1 & $\begin{array}{l}\text { Benih yang } \\
\text { baik jatuh ke } \\
\text { sungai, } \\
\text { menjadi pulau. } \\
\text { Benih yang } \\
\text { buruk, } \\
\text { jatuh ke bumi } \\
\text { menjadi } \\
\text { bencana. }\end{array}$ & T. Syahar & $\begin{array}{l}\text { i) ada dan disampaikan } \\
\text { pada "Ritual Jamuan } \\
\text { Sampan"; } \\
\text { ii) Jangan sekali-sekali } \\
\text { berbuat tidak baik } \\
\text { terhadap sungai; } \\
\text { iii) sungai sumber } \\
\text { kehidupan yang dapat } \\
\text { "berbahasa" }\end{array}$ \\
\hline 2 & $\begin{array}{l}\text { Tak tumbuh tak } \\
\text { melata, } \\
\text { tak sungguh } \\
\text { orang tak kata }\end{array}$ & $\begin{array}{l}\text { Ridwan } \\
\text { Trg. }\end{array}$ & $\begin{array}{l}\text { i)ada dan disampaikan } \\
\text { saat "Ritual Jamu } \\
\text { Sungai"; } \\
\text { ii)tidak disampaikan bila } \\
\text { tidak mungkin ada dan } \\
\text { terjadi; } \\
\text { iii)sesuatu perbuatan di } \\
\text { sungai nyata ada yang } \\
\text { melihat dan } \\
\text { mengetahuinya }\end{array}$ \\
\hline 3 & $\begin{array}{l}\text { Genggam bara } \\
\text { api, } \\
\text { biar sampai } \\
\text { jadi arang. }\end{array}$ & Zakaria & $\begin{array}{l}\text { i)wujud dan disampaikan } \\
\text { saat "Ritual Jamu } \\
\text { Kampung"; } \\
\text { ii)kehidupan di tepi sungai } \\
\text { perlu fisik dan jiwa yang } \\
\text { kuat; } \\
\text { iii)Perilaku di sungai perlu } \\
\text { kesadaran dan kesabaran } \\
\text { agar selamat dunia } \\
\text { akhirat. }\end{array}$ \\
\hline
\end{tabular}

\begin{tabular}{|c|c|c|c|}
\hline 4 & $\begin{array}{l}\text { Sakit mata } \\
\text { memandang, } \\
\text { lebih berat } \\
\text { bahu memikul }\end{array}$ & Badar & $\begin{array}{l}\text { i)ada dan disampaikan } \\
\text { saat "Ritual Cukur } \\
\text { Rambut"; } \\
\text { ii)Mudarat dari sesuatu } \\
\text { yang dibuat di sungai } \\
\text { berat merasakan dan } \\
\text { menjalaninya; } \\
\text { iii)Manfaat sungai } \\
\text { berubah menjadi } \\
\text { kemudaratan hidup. }\end{array}$ \\
\hline 5 & $\begin{array}{l}\text { Sehari } \\
\text { selembar } \\
\text { benang, } \\
\text { lama-lama } \\
\text { menjadi kain. }\end{array}$ & T. Katik & $\begin{array}{l}\text { i)ada dan disampaikan } \\
\text { saat "Ritual Khitanan"; } \\
\text { ii)Perbuatan yang secil } \\
\text { apapun akan membawa } \\
\text { akibat yang besar; } \\
\text { iii)Sesungguh apapun yang } \\
\text { dilakukan tetap membawa } \\
\text { bencana. }\end{array}$ \\
\hline 6 & $\begin{array}{l}\text { Berani karena } \\
\text { benar, } \\
\text { takut karena } \\
\text { salah }\end{array}$ & Sormin & $\begin{array}{l}\text { i)ada dan disampaikan } \\
\text { saat "Istiadat khatam } \\
\text { Ngaji"; } \\
\text { ii)Lakukan pada sesuatu } \\
\text { perbuatan sesuai fungsi } \\
\text { dan faedahnya; } \\
\text { ii) berpada pada berbuat } \\
\text { kepada siapa-siapa saja. }\end{array}$ \\
\hline 7 & $\begin{array}{l}\text { Ular menyusur } \\
\text { akar, } \\
\text { tidak akan } \\
\text { hilang bisanya. }\end{array}$ & Awang & $\begin{array}{l}\text { i)ada dan disampaikan } \\
\text { saat "Ritual Jamu } \\
\text { Sampat"; } \\
\text { ii)Manfaatkan sesuatu } \\
\text { yang berfaedah bagi } \\
\text { sungai; } \\
\text { iii)tidak ada jalan sesuatu } \\
\text { yang baik akan menjadi } \\
\text { buruk. }\end{array}$ \\
\hline 8 & $\begin{array}{l}\text { Sekilas ikan di } \\
\text { air, } \\
\text { tahu jantan }\end{array}$ & Ajang & $\begin{array}{l}\text { i) diperoleh saat } \\
\text { disampaikan pada "Ritual } \\
\text { Membelah Kayu”; }\end{array}$ \\
\hline
\end{tabular}




\begin{tabular}{|c|c|c|c|}
\hline No. & $\begin{array}{l}\text { Expressions/ } \\
\text { Petuah Adat }\end{array}$ & Informan & Description \\
\hline & betinanya & & $\begin{array}{l}\text { ii)Banyak manfaat dan } \\
\text { faedah sungai bagi } \\
\text { kehidupan sehari-hari; } \\
\text { iii) sederas air sungai, } \\
\text { seketika pula mudarat } \\
\text { yang diperoleh bila } \\
\text { berbuat yang tidak baik } \\
\text { terhadap sungai. }\end{array}$ \\
\hline 9 & $\begin{array}{l}\text { Beruk di hutan } \\
\text { disusukan, } \\
\text { anak digendong } \\
\text { mati kelaparan }\end{array}$ & Syaiful & $\begin{array}{l}\text { i) diperoleh saat } \\
\text { disampaikan pada "Ritual } \\
\text { Jamu Sungai"; } \\
\text { ii)serugi apapun demi } \\
\text { sungai pasti akan } \\
\text { membawa faedah yang } \\
\text { lebih besar; } \\
\text { ii)sehancur-hancur } \\
\text { kehidupan lebih poranda } \\
\text { pada masa terjadi } \\
\text { bencana. } \\
\end{array}$ \\
\hline 10 & $\begin{array}{l}\text { Lepaskan } \\
\text { anjing tercepit, } \\
\text { air susu dibalas } \\
\text { tuba }\end{array}$ & Bahaudin & $\begin{array}{l}\text { i)ada dan disampaikan } \\
\text { saat "Ritual Jamu } \\
\text { Kampung"; } \\
\text { ii)Berbuat tidak baik } \\
\text { terhadap sungai pasti } \\
\text { ditelan bala. } \\
\end{array}$ \\
\hline 11 & $\begin{array}{l}\text { Cacing } \\
\text { menyolok mata, } \\
\text { kulit } \\
\text { menunjukkan } \\
\text { isi }\end{array}$ & M. Lokot & $\begin{array}{l}\text { i) ada dan disampaikan } \\
\text { saat "Ritual Jamu } \\
\text { Sampan"; } \\
\text { ii)Sakitnya dilanda banjir } \\
\text { membawa padah menjadi } \\
\text { sengsara. }\end{array}$ \\
\hline 12 & $\begin{array}{l}\text { Kaduk naik } \\
\text { junjung; } \\
\text { harapkan } \\
\text { pagar, } \\
\text { tapi pagar } \\
\text { makan padi }\end{array}$ & Ruslan & $\begin{array}{l}\text { i)ada dan disampaikan } \\
\text { saat "Musyawarah } \\
\text { Kampung"; } \\
\text { ii)Berharap dari yang } \\
\text { tidak baik menyengsarakan } \\
\text { jiwa; } \\
\text { iii)berlawanan kepada } \\
\text { kebaikan pasti mendapat } \\
\text { celaan dari siapa saja. }\end{array}$ \\
\hline
\end{tabular}

\section{DISCUSSIONS}

Narration text entitled "Pelanduk Terkial-kial" (PTK) and tradition expressions or Ungkapan Petuah Adat (UPA) above, described in right columns are the meaning of each expression. If refers to the media they express, ritus or ritual of Malay society customs in Billah river. It introduces the connected pattern and ability in supporting one subject and object, tied up with the river cosmicfor uniting the society sovereignty toward Billah river.

The meaning of PTK and UPA shows that Billah river main tenancecould be built through norms and values building. This includes: i) Behave based on halal teaching, meaning every action should be based on Islam teaching by obeying custom and government rules; ii). Do good deeds, consisting of sincerity and selfawareness; iii). Perform positive behavior, beneficial to oneself, society, nation and country; iv).Refer to knowledge to decide something, every suggestion was made based on knowledge; v). Behave properly, doing thing properly and fit to oneself; vi). Be loyal, acting loyally when working or doing something for society; vii) have dedication, commiting to the dedication when performing, Petuah and Nasihat (advice); viii). Behave politely, that is noble and gentle; ix). Be punctual, appreciating time by being punctual.

Through this reception mechanism as stated in the expression text or Petuah Adat, it clearly shows that Malay people dwellingaround Billah riverside know the meaning of their lives. They know who and what in their environment. Due to that, Malay people living at the upper and lower area of the Billah river, Labuhan Batu regency were able to show their thinking and understanding patternsas guidance to alert their generation in understanding complicated problem due to living in the Billah riverside area.

Basically, PTK and UPA 's meaning is metaphor referring to the Malay society lives. Realizing the importance of internalizingPTK and UPA valuesto preserve Billah riverside area. This Malay society personal area with the translated the values into their lives. It is stated that is the Malay embryo in Billah river to make the existence of role and function of oral literature in their lives by making the norms and the values, based on the literature work, as the life guidance at the river cosmic and their God Allah ..itulah benih Melayu di Sungai Billah yang berpelampung meredah lautan kehidupannya di Sungai Billah melimbang dirinya dipelimbang demi penataan DAS Billah untuk diperlihatkan nilai emas kepada masyarakat terhadap buana sungai dan Tuhannya [5]

\section{CONCLUSION AND SUGGESTION}

\section{Conclusion}

Based on the discussions above as the existence of Malay oral literature texts, expressions and Petuah Adat as local wisdom of the society living in Billah riverside area, could be concluded that those expressions have aroused the society awareness towards their relationship (both physically and mentally) with their environment. This understanding could maintain their awareness and be able them to prevent flood to occur. Observing the situation where the expressions is uttered and given, it could be realized that each expression has dynamic strength to direct the society behavior in order to be more positive. Because each value is natural and sacred, it is strategic to use the value to build society awareness and to maintain their positive behavior toward the river. Moreover, the emotional bonding between the values of PTK and PTA and the society is so strong. That can rise their confidence and dignity when dwelling around the river.

\section{Suggestion}

To empower the values and norms revealed in Malay oral literature in Billah riverside toward its society, media is highly required to help ease and accelerate the society awareness. The media could be a poster, as the visual aid, to combine the strong plan and fast message delivering to catch the society attention. It is not merely just giving suggestion but acting so it will be strongly absorb in memory and life. Principally, poster is a suggestion in illustrated form, with the purpose of 
catching attention, offering, motivating, or showing main idea, a fact or certain event. To serve that purpose, the poster will be placed at certain public areas and along the area of Billah riverside. Poster as media in planning and preserving Billahriver is not only based on sequences of wordsto deliver special ideas or special messages but also the power of those meaningful words referring to norms and values in PTK and UPA.

\section{REFERENCES}

[1] Agger, Ben. "Teori Sosial Kritis, Kritik, Penerapan dan Implikasinya. Yogyakarta: Kreasi Wacana. 2013.

[2] [Badan Pusat Statistik Kabupaten Labuhan Batu. "Labuhan Batu in Figures". Labuhan Batu: Cooperation of Satistic of LabuhanBatu Regency and Archieves, Library and Documentary Office of LabuhanB atu Regency. 2013

[3] Hoang Vinh Hung, Rajib Shaw, Masami Kobayasi. "Flood risk Management for The Riverside Urban Areas of Hanoi: The Need for Synergy Urban Development and Risk Management Policy". Disaster Prevention and Management: An International Journal. Vol.19. Issue 1.ISSN: 09653562. 2010
[4] Korner, Axel. "The Risorgimento's literary canon and The Aesthetic of Reception: Some Methodological Consideration: Journal of The Association for the Study of Ethnicity and Nationalism (ASEN). Vol 15.Issue 3. July 2009

[5] Salleh, Khalid. "Melayu Hilang di Dunia". Kuala Lumpur: Rentak Positif. Sdn. Bhd. 2011

[6] Syaifuddin, Wan. "Pemikiran Kreatif dan Sastra Melayu Tradisi”. Yogyakarta: Penerbit Gading. 2016

[7] Syaifuddin, Wan. "Buana Sungai, Hutan, dan Adat Melayu Suluh dalam Membangun" dalam "Pemikiran Guru Besar Universitas Sumatera Utara untuk Pembangunan. Medan: USU Press.2017

[8] Syaifuddin, Wan. "The River Planning based on Local Wisdom (Case study: Upper reaches of Sungai Deli Medan, North Sumatera)". Proceedings International Conference on Arts and Culture p. 310. ISBN 978-602-60820-2-2.Bandung: Post Graduate Program of ISBI Bandung. 2018

[9] Venkatesan, Priya.'Reception studies in France: Social Context, Reader Interpretation and the role of Julia Kristeva". Vol.9. Number .p.111-124. Spring: The Johns Hopkin University Press. 2009. 